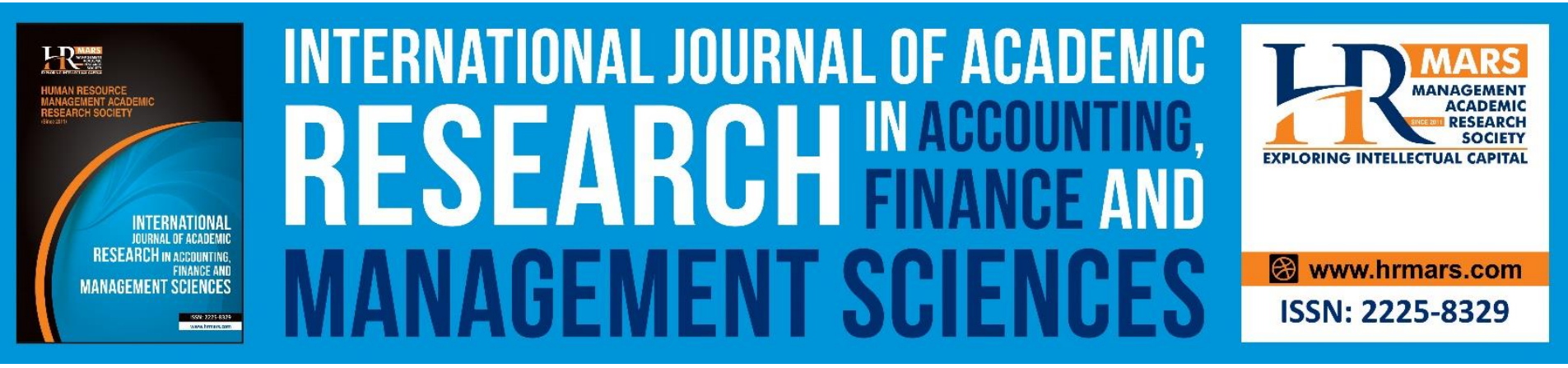

\title{
Migrants' Remittances, Financial Development and Economic Growth in Nigeria: The Interaction Effect.
}

Falade, Abidemi Olufemi Olusegun, Aladejana, S. Aliu, Okeowo, Idowu Adeniyi, Oluwalana, Feyisayo Abosede

To Link this Article: http://dx.doi.org/10.6007/IJARAFMS/v11-i1/9139

DOI:10.6007/IJARAFMS /v11-i1/9139

Received: 19 December 2020, Revised: 21 January 2021, Accepted: 10 February 2021

Published Online: 27 February 2021

In-Text Citation: (Falade et al., 2021)

To Cite this Article: Falade, A. O. O., Aladejana, S. A., Okeowo, I. A., \& Oluwalana, F. A. (2021). Migrants' Remittances, Financial Development and Economic Growth in Nigeria: The Interaction Effect. International Journal of Academic Research in Accounting Finance and Management Sciences, 11(1), 271-284.

Copyright: (c) 2021 The Author(s)

Published by Human Resource Management Academic Research Society (www.hrmars.com)

This article is published under the Creative Commons Attribution (CC BY 4.0) license. Anyone may reproduce, distribute, translate and create derivative works of this article (for both commercial and non-commercial purposes), subject to full attribution to the original publication and authors. The full terms of this license may be seen at: http://creativecommons.org/licences/by/4.0/legalcode

Vol. 11, No. 1, 2021, Pg. 271 - 284

http://hrmars.com/index.php/pages/detail/IJARAFMS

JOURNAL HOMEPAGE

Full Terms \& Conditions of access and use can be found at http://hrmars.com/index.php/pages/detail/publication-ethics 


\title{
Migrants' Remittances, Financial Development and Economic Growth in Nigeria: The Interaction Effect.
}

\author{
Falade, Abidemi Olufemi Olusegun ${ }^{1}$, Aladejana, S. Aliu², Okeowo, \\ Idowu Adeniyi Ph. D ${ }^{3}$, Oluwalana, Feyisayo Abosede 4
}

${ }^{1}$ Senate Research Consulting Firm, Akungba-Akoko, Ondo-State, ${ }^{2 \& 3}$ Department of Economics, Samuel Adegboyega University,Ogwa, Edo State, Nigeria, ${ }^{4}$ Postgraduate student, Department of Economics, Federal University Oye Ekiti, Ekiti State. Nigeria, ${ }^{4}$ Postgraduate student, Department of Economics, Federal University Oye Ekiti, Ekiti State. Nigeria.

Email: Prof.femmy@yahoo.com, aladejana26@gmail.com,Okeowo4hope@gmail.com, feyidada79@gmail.com

\begin{abstract}
Previous studied had identified that migrants' remittances are too weak to stimulate economic growth in emerging economies. It is in the realization of this problem that this study examined the interaction effect of migrants' remittances and financial development on economic from 1986-2019 in Nigeria.

The study employed Augmented Dickey-Fuller (ADF) and Phillip Peron (PP) unit root test, Johansen Co-integration and Vector Error Correction Model technique (VECM).

Both the ADF and PP indicated that real-GDP, migrants' remittance, financial development index, the interaction of migrants' remittance and financial development index, and trade openness were integrated of order $(\Delta=1)$. Also, the co-integration relationship was confirmed by the Johansen technique. The VECM confirmed that interaction of migrants' remittance and financial development index and trade openness were directly related to real-GDP; while migrants' remittance inflow was indirectly related to it with their t-statistics (2.21160), (1.82206), (2.19183) greater than t-values at $\left(t_{0.05}=2.042\right)$ and $\left(t_{0.1}=1.697\right)$ respectively. Also, financial development index exhibited an inverse relationship but non-significance.

This study therefore, concluded that the extent to which migrants' remittances influence economic growth in Nigeria depends on how developed her financial market. It was recommended that the Central bank of Nigeria (CBN) should reduce charges on migrants' remittance inflow to Nigeria in line with other African countries to discourage remittances sending through informal channels. The CBN is also encouraged to improve her regulatory framework such as financial instruments, the payment system, financial services and financial institutions in line with $21^{\text {st }}$ century standards.

Keywords: Migrant Remittance, Financial Development, Exchange Rate, Trade Openness, Vector Error Correction Model Technique (VECM)
\end{abstract}


INTERNATIONAL JOURNAL OF ACADEMIC RESEARCH IN ACCOUNTING, FINANCE AND MANAGEMENT SCIENCES

Vol. 11, No. 1, 2021, E-ISSN: 2225-8329 @ 2021 HRMARS

\section{Introduction}

The upsurge rise in migrants' remittances to emerging countries especially the Sub-Sahara countries, has become an important source of foreign funds. In the year 2016 alone world total remittance stood at $\$ 585.1$ billion dollars of which developing economies received 442 billion dollars (World Bank, 2017). In the year 2017, it was $\$ 613$ billion indicating an increase of $7 \%$ when compared to 2016 . In that same year $\$ 613$ billion dollars representing 73.4\% of the entire money went to developing countries. In 2018, it was $\$ 616$ billion dollars. Nigeria alone has received remittances up to $\$ 246.119$ billion from 1977-2016 (Falade, 2019). These figures only capture remittances received through formal channels, while inflows through informal channels are believed to be considerable. In 2011 for instance, the total remittance inflows to Nigeria was $\$ 10.681$ billion as against $\$ 1.392$ billion in 2004, which was about an increase of $76 \%$ in 10 years. Meanwhile, there is a high tendency that migrants' remittance will continue to grow, with remittance inflow to low middle-income countries growing at a predictable rate of $4.1 \%$ and expected to be $\$ 485$ billion. Nigeria was the largest recipient of remittances in Sub-Saharan Africa in 2017 with a total value of $\$ 22$ billion.

According to Falade (2019) transfer of remittance inflows involves both formal and informal channels. The formal channel is known as the documented channel while the informal channel is known as the undocumented channel. In many developing economies, most of the remittances inflow received pass through the informal channel or undocumented channel. For instance, World Bank (2010) remarked that more than $50 \%$ of the remittances receive in developing countries passed through informal channels; therefore, resulting in under-estimation of total remittances inflow received. Also, International Monetary Fund (2009) corroborates the claim and disclosed that lack of weak financial institution gives room for use of informal channels as means of transferring funds to African countries and if remittances sent through the undocumented channel are part of the total remittance inflow received by African countries, total remittances would be higher than the present value by $50 \%$. Ratha (2005) attributed the rise in the undocumented channel as a means of transferring funds to the weak financial institutions in many developing countries. In Nigeria, for instance, unstable and distortion of exchange rate policy coupled with unfavourable government policies about the financial market encourage migrants to embrace informal channels or undocumented channels as a means of remitting money back home. On this note, Ali and Hassan (2008) implore the African apex banks to improve on their data collection on formal and informal remittances to know the actual value of remittance inflows received years. Ojapinwa, (2015) also revealed that in Nigeria, workers' remittances by international migrants have increased drastically during the last four decades, but lack of well-developed financial institutions under-estimate its actual value.

The importance of remittances to financial development cannot be overemphasis since it has been confirmed in some quarters that remittances stimulate financial development. On this note, the World Bank (2013) emphasizes building effective institutions and promoting financial development as priorities now and in the future to stimulate economic growth. Hamma (2016) revealed that there is a need for financial development to complement remittances to ensure economic growth. Also, in the Nigerian context Babatunde, Olayinka and Okwy (2011) revealed that remittances stimulate financial development by providing funds to both the private sector and the public sector. At present the inflow of migrants' remittances serves as a growing source of foreign funds for many developing countries Nigeria inclusive. These inflows double the official aids received by developing countries. In 2016 alone, the developing countries received remittances up to US\$585.1 billion, while from 19772016, Nigeria received remittance up to \$246.119 billion (World Bank, 2017; Falade, 2019). Given 
INTERNATIONAL JOURNAL OF ACADEMIC RESEARCH IN ACCOUNTING, FINANCE AND

MANAGEMENT SCIENCES

Vol. 11, No. 1, 2021, E-ISSN: 2225-8329 @ 2021 HRMARS

this, the study examined the interaction effect of migrants' remittances and financial development on economic growth in Nigeria.

\section{Statement of the Problem}

Past studies had identified the upward surge in remittances inflow to developing countries with many of these studies examined its effect on different macro-economic variables; such as on poverty, financial development, education and many. For instance, Iheke (2012); Koay and Keong (2013) and Muhammad, Arif, and Qayyum (2012) have established a direct and significant effect of remittances inflow on economic growth. Also, studies that include Adeleye (2018), and Anyawu and Erhjikarpor (2009) in Nigeria arrived at the same conclusions. Also, studies that include Adenutsi (2011); Catrinescu, Miguel, Piracha, and Quillin, (2009); Jongwanich (2008); Pradhan, Upadhyay, and Upadhyaya (2008); Ratha (2005) had confirmed that remittances stimulate financial development. In the Nigerian context too Babatunde, Olayinka and Okwy (2011); Ojapinwa (2015) have arrived at varying conclusions over the effect which remittances had on financial development over the years. Also, Aladejana et al (2020) discovered that remittances have a strong and statistically impact on poverty reduction; while, Falade (2019) concluded that such effect is tentative on poverty reduction due to the fact that house-hold spend more of remittance received on consumption. Despite these findings, migrants' remittances had been identified to be too weak to stimulate growth. Therefore, a strong financial development system is needed. It is in the realization of this problem that this study investigated the interaction effect of migrants' remittances and financial development on economic growth in Nigeria from 1986-2019.

The study was motivated by the fact that over the years, Nigerian level of financial development and international remittances have not explicitly and positively influenced economic growth. Therefore, the study contributed to existing knowledge through empirical validation by showing that the impact of remittances on economic growth depends on the level of financial development.

\section{Literature Review}

Englama (2009) defined migrants' remittance as money transfer by workers in foreign countries to their place of birth or home countries. International Monetary Fund (2009) interprets it as the compensation of employees or workers that are transfers to their households in the country of origin. It also involves wage, salary and value of in-kind benefits received by employees residing abroad. Falade (2019) sees it has a movement of cash or kind from migrants reside country to his country of origin which can either be through formal or informal channels. The formal channel is known as the documented channel, while the informal channel is known as the undocumented channel. The major players involved in remittance inflow are the migrant/ sender, channel and receiver (Falade, 2019). The effectiveness of migrants' remittance on economic growth depends on channel and the usage of the proceeds received by the receiver. On channel, it hangs on financial development of financial institutions of the recipient's country. This plays major role due to inter-play of macro-economic indices that respond to both monetary and fiscal mechanism. For the receiver/ household, when house-hold invests remittances received into more productive economic activities, there would be increase in consumption pattern and saving.

Financial development involves continuous quality delivery by financial institutions in terms of efficiency in financial instruments, the payment system, and financial services. Past studies and literature had identified different indicators variable as a proxy for financial development using 
INTERNATIONAL JOURNAL OF ACADEMIC RESEARCH IN ACCOUNTING, FINANCE AND MANAGEMENT SCIENCES

Vol. 11, No. 1, 2021, E-ISSN: 2225-8329 @ 2021 HRMARS

specific characteristics of the financial system of countries involved as selection criteria for the proxy variables. The selected proxy variables for financial development index are embedded in the size of the financial market, type of financial institutions present and type of monetary system adopt in such a country. Past studies that include Jung, (1986); Darrat (1999); Liu, Song, and Romilly (1997) had identified M1, M2 and M3 to nominal GDP as the financial sector indicators. Also, Babatunde et al., (2011); Hamma (2016) had identified the value of credit to the private sector to GDP in constant prices or money supply (M2) to GDP as a proxy. In this present $21^{\text {st }}$-century financial sector development has embraced technology input, therefore, become a central nerve to economic development through the availability of funds and other financial services. Presently in developing countries it has improved capital accumulation, technological progress and increases accessibility to funding by low-income households.

The interaction effect means that a combination of two or more variables to effect change on other variables. In this study, it implies that the combination of migrants' remittance and financial development to jointly cause change in economic growth. Economic growth encompasses so many factors, especially growth that involves citizens' welfare. As a result of this, one variable maybe too weak to significantly influence change in it. It has been noted in past studies that migrants' remittance is too weak to stimulate growth. For instance, Altin (2013), Ahamada and Coulibaly (2013), Zuniga (2011), Acosta, Lartey, and Mandelman (2007) and Chami, Fullenkamp, and Jahjah (2003) discovered in their separate studies that remittances have retarded growth in developing nations. The interaction effect of migrants' remittance and financial development means that the combine effects of migrants' remittance and financial development on economic growth.

\section{Empirical Studies}

Studies carried out-side Nigerian shore that includes Iheke (2012); Koay and Choong (2013) and Muhammad, Arif, and Qayyum (2012) had confirmed that remittances had a direct and significant effect on economic growth. Also, studies that include Adeleye (2018), and Anyawu and Erhjikarpor (2009) in Nigeria arrived at the same conclusions. In the same way, studies that include Adenutsi (2010); Catrinescu (2009); Jongwanich (2007); Pradhan et al., (2008) and Ratha (2005) had confirmed that remittances stimulate financial development. In the Nigerian context too Babatunde, Olayinka and Okwy (2011) and Ojapinwa (2015) have arrived at varying conclusions over the impact which remittances had on financial development. Also, Hamma (2016) examined the combined effect of remittances and financial development on economic growth in MENA countries. In Nigerian context studies are still lacking in this area. Hence, this study filled this gap, by examining the interaction effect of remittances and financial development on economic growth in Nigeria.

\section{Theoretical Framework}

The theory of exogenous growth was adopted as the theoretical framework for this study. The theory assumes that growth could only occurs in the economy as a result of influence outside the economy's boundary. According to the theory, growth in the economy is a direct function of technological progress which is often endogenously determined by model outside the economy. For this study, exogenous growth is adopted due to the fact that technological progress has helped financial institution through financial development by easy the facilitation and movement of funds from one country to another which directly influence economy growth in a country. For instance, technological progress has reduced under-estimation of total remittances inflow received by recipient's country, 
INTERNATIONAL JOURNAL OF ACADEMIC RESEARCH IN ACCOUNTING, FINANCE AND MANAGEMENT SCIENCES

Vol. 11, No. 1, 2021, E-ISSN: 2225-8329 @ 2021 HRMARS

especially if the migrant's remittance passes through formal channel. Also, the technological progress has facilitated development in financial institution in areas like, deposit money bank, microfinances, Automated Teller Machines (ATMS), Point of Sale (POS), mobile agent and other forms of financial services. According to Solow (1991), reduction in aggregate production could be due to climate deficiencies or other factors not accounted for in the model. The Cobb-Douglas (1928) production function, also known as the neoclassical production function is used to expressed the theory as follows:

$$
Y=A L^{\beta} K^{\alpha} \quad \ldots . . . . . . . . . .(i)
$$

Where: $\alpha+\beta=1, Y=$ output, $L=$ labour, and $K=$ capital

In equation $i$ above, there could only be improvement in output from $Y$ to $Y^{1}$ when technology is added to the equation $i$. Therefore, adding technology to equation $i$, we have

$$
Y^{1}=T\left(A L^{b} K^{\alpha}\right) \ldots . . . . . \quad \ldots . . . \text { (ii) }
$$

Where $Y^{1}=$ Improved total output, $\mathrm{T}=$ the rate of technological progress which changes over time.

From the equation ii above, the inclusion of the technology variable freed the neoclassical theory from the doom saying of Malthus and Ricardo which indicates the ultimate destiny of mature economies in terms of the more acceptable but still rather conservative stationary state, where all real variables grow at a constant and proportional rate.

\section{Data and Methodology \\ Model}

The model for this study was built on Hamma (2016) model with modification and inclusion of trade openness variable according to the exogenous growth theory adopted for this study. The baseline model of Hamma (2016) is given below in linear form;

Where;

$$
W G D P=(R E M, F I N D V P, R E M * F I N D V P, X, Л, Y) \ldots \ldots \text { (iii) }
$$

WGDP $=$ Growth of real GDP per capita, REM = Remittances inflow,

FINDVP $=$ Financial development, REM $*$ FINDVP $=$ remittances inflow and financial development, $X=$ Standard set of determinants of economic growth, $\Omega=\quad$ The time-specific effect, $Y=A n$ unobserved country-specific effect

The modified model of Hamma (2016) for this study was given below;

$$
R G D P=f\left(R E M, F I D V, R E M^{*} F I D V, O P E N\right) \ldots \ldots \text {... (iv) }
$$

Where; RGDP = Real-GDP (proxy for economic growth), $R E M=$ Migrants' remittance inflow, FIDV = Financial development index, REM*FIDV = The interaction of migrants' remittances and financial development, and OPEN = Trade openness

The rationale for modifying Hamma (2016) model is because of two reasons. First, the exogenous growth is part of neo-classical theory that assumes free trade; therefore, trade openness was included in the model. In addition, only variables of interest according to the objective were included in the model.

In the equation iv above, three variables that include real-GDP, migrants' remittance and interaction of migrants' remittances and financial development were converted into natural log form in order to avoid scaling problems that occur due to high variables. The rationale for converting them was that they all have high values compare to other variables in the model that were in ratio form. Therefore, it helps to eliminate having estimated co-efficient values more than $100 \%$ in their absolute values. Otherwise known as scaling problem. 
INTERNATIONAL JOURNAL OF ACADEMIC RESEARCH IN ACCOUNTING, FINANCE AND MANAGEMENT SCIENCES

Vol. 11, No. 1, 2021, E-ISSN: 2225-8329 @ 2021 HRMARS

In econometric form, equation (iv) becomes

$$
\ln R G D P=\pi_{0}+\pi_{1} \ln R E M+\pi_{2} F I D V+\pi_{3} \ln R E M * F I D V+\pi_{4} O P E N+\mu_{t}
$$

The a-priori expectation is: $\pi_{1}>0, \pi_{2}>0, \pi_{3}>0$, and $0>\pi_{4}>0$

Table 1: Definition and Measurement of Variable

\begin{tabular}{|l|l|l|}
\hline Variables & Measurement & Source \\
\hline RGDP & $\begin{array}{l}\text { The total value of goods and services produced } \\
\text { yearly which have been adjusted for price changes } \\
\text { (i.e. inflation and deflation) }\end{array}$ & $\begin{array}{l}\text { CBN Statistical Bulletin } \\
2019\end{array}$ \\
\hline FIDV & $\begin{array}{l}\text { Percentage of the value of credit to the private sector } \\
\text { divided by GDP in constant prices. }\end{array}$ & $\begin{array}{l}\text { CBN Statistical Bulletin } \\
2019\end{array}$ \\
\hline REM & $\begin{array}{l}\text { The total value of transfer money by foreign workers } \\
\text { to their home country. }\end{array}$ & $\begin{array}{l}\text { World Bank Development } \\
\text { Indicator, 2019 }\end{array}$ \\
\hline REM*FIDV & $\begin{array}{l}\text { Multiplication of financial development index value } \\
\text { and migrants' remittance inflow value }\end{array}$ & Researcher's compilation \\
\hline OPEN & $\begin{array}{l}\text { The sum of exports and import of goods and services } \\
\text { divided by GDP in constant prices }\end{array}$ & $\begin{array}{l}\text { CBN Statistical Bulletin } \\
2019\end{array}$ \\
\hline
\end{tabular}

Result and Discussion

Table 2: Unit Root Test

\begin{tabular}{|l|l|l|l|l|l|l|l|l|}
\hline \multicolumn{2}{|l|}{ Augmented Dickey Fuller (ADF) } \\
\hline Variable & $\begin{array}{l}\text { Test } \\
\text { Statistic }\end{array}$ & $\begin{array}{l}5 \% \\
\text { value critical }\end{array}$ & Level & S & $\begin{array}{l}\text { Test } \\
\text { Statistic }\end{array}$ & $\begin{array}{l}\text { 5\% critical } \\
\text { value }\end{array}$ & Level & S \\
\hline InRGDP & $/ 3.182060 /$ & $/ 2.960411 /$ & $\mathrm{I}(1)$ & $\mathrm{S}$ & $/ 3.182060 /$ & $/ 2.960411 /$ & $\mathrm{I}(1)$ & $\mathrm{S}$ \\
\hline InREM & $/ 6.589511 /$ & $/ 2.960411 /$ & $\mathrm{I}(1)$ & $\mathrm{S}$ & $/ 6.488589 /$ & $/ 2.960411 /$ & $\mathrm{I}(1)$ & $\mathrm{S}$ \\
\hline FIDV & $/ 5.069652 /$ & $/ 2.960411 /$ & $\mathrm{I}(1)$ & $\mathrm{S}$ & $/ 5.132461 /$ & $/ 2.960411 /$ & $\mathrm{I}(1)$ & $\mathrm{S}$ \\
\hline InREM*FIDV & $/ 6.408033 /$ & $/ 2.960411 /$ & $\mathrm{I}(1)$ & $\mathrm{S}$ & $/ 6.410882 /$ & $/ 2.960411 /$ & $\mathrm{I}(1)$ & $\mathrm{S}$ \\
\hline OPEN & $/ 6.563847 /$ & $/ 2.960411 /$ & $1(1)$ & $\mathrm{S}$ & $/ 6.579185 /$ & $/ 2.960411 /$ & $\mathrm{I}(1)$ & $\mathrm{S}$ \\
\hline \multicolumn{7}{|l|}{ Sindicates stationary }
\end{tabular}

Source: Researcher's Compilation from E-view-9

The ADF and PP results indicated that all the variables were integrated order of one $(\Delta=1)$. This, therefore, gave justification for the use of Vector Error Correction Model technique (VECM). The economic implication of this finding is that at integrated of order $(\Delta=1)$, all the variables were individually stable without influence from other economics variables. Therefore, they become independent of themselves. 
INTERNATIONAL JOURNAL OF ACADEMIC RESEARCH IN ACCOUNTING, FINANCE AND MANAGEMENT SCIENCES

Vol. 11, No. 1, 2021, E-ISSN: 2225-8329 @ 2021 HRMARS

Table 3: Johansen Co-Integration Test

\begin{tabular}{|l|l|l|l|l|l|l|}
\hline \multicolumn{2}{|l|}{ Trace Max-Eingen Statistics } & \multicolumn{2}{l|}{ Max-Eingen Statistics } \\
\hline$H_{0}$ & $\begin{array}{l}\text { Trace } \\
\text { Statistics }\end{array}$ & $\begin{array}{l}\text { Crical value at level } \\
\text { 5rob level }\end{array}$ & $\begin{array}{l}\text { Max-Eingen } \\
\text { Statistics }\end{array}$ & $\begin{array}{l}\text { Critical value at } \\
\text { Prob }\end{array}$ & \\
\hline$r=0$ & 217.5653 & 95.75366 & $0.0000^{* *}$ & 101.3480 & 40.07757 & $0.0000^{* *}$ \\
\hline$r=1$ & 116.2173 & 69.81889 & $0.0000 * *$ & 73.81587 & 33.87687 & $0.0000^{* *}$ \\
\hline$r=2$ & 42.40143 & 47.85613 & 0.1478 & 17.31207 & 27.58434 & 0.5532 \\
\hline$r=3$ & 25.08936 & 29.79707 & 0.1583 & 13.21328 & 21.13162 & 0.4328 \\
\hline$r=4$ & 11.87608 & 15.49471 & 0.1630 & 11.84864 & 14.26460 & 0.1165 \\
\hline$r=5$ & 0.027436 & 3.841466 & 0.8684 & 0.027436 & 3.841466 & 0.8684 \\
\hline$* *$ indicate rejection of null hypothesis at the 0.05 level & & \\
\hline
\end{tabular}

Source: Researcher's Compilation from E-view-9

As indicated in Table 3 above, the $\mathrm{t}$ - statistics associated to the co-integration analysis of both Trace and Max-Eingen statistics at $r=0$ and $r=1$ were higher than the critical value at $5 \%$ significance level. The implication of this result was that there was evidence of long-run association between the variables.

Table 4: Lag Order Selection (Max 1)

\begin{tabular}{|l|l|l|l|l|l|l|}
\hline Lag & LogL & $L R$ & $F P E$ & AIC & $S C$ & $H Q$ \\
\hline 0 & -55.97699 & NA & $2.20 \mathrm{e}-06$ & 3.998515 & 4.276061 & 4.088988 \\
\hline 1 & 110.7405 & $258.1432 *$ & $5.01 \mathrm{e}-10$ & -4.434873 & $-2.492052 *$ & $-3.801562 *$ \\
\hline 2 & 152.1249 & 48.05926 & $4.70 \mathrm{e}-10 *$ & $-4.782251^{*}$ & -1.174154 & -3.606102 \\
\hline * indicates lag order selected by the criterion & & & \\
\hline
\end{tabular}

Source: Researcher's Compilation from E-view-9

In table 4 above, majority of the criteria selector selected the maximum lag order of 1 . Therefore, the study selected maximum lag order of 1 for the VECM

Vector Error Correction Estimates

Table 5: Vector Error Correction Estimates

\begin{tabular}{|c|c|c|c|c|}
\hline \multirow[t]{3}{*}{ CointEq1: } & \multirow{3}{*}{$\begin{array}{r}-0.031810 \\
(0.01263) \\
{[-2.51861]}\end{array}$} & \multicolumn{3}{|c|}{$R^{2}: 0.509415$} \\
\hline & & \multicolumn{3}{|c|}{ Adj $R^{2}$ squared: 0.331020} \\
\hline & & \multicolumn{3}{|c|}{ F-statistic : 2.855548} \\
\hline $\begin{array}{l}\Delta(\ln R G D P(- \\
1))\end{array}$ & $\Delta(\operatorname{lnREM}(-1))$ & $\Delta(\operatorname{FIDV}(-1))$ & $\Delta(\operatorname{lnREM} *$ FIDV $(-1))$ & $\Delta($ OPEN $(-1))$ \\
\hline $\begin{array}{l}0.371452 \\
(0.17319) \\
{\left[2.14475^{*}\right]}\end{array}$ & $\begin{array}{l}-0.073346 \\
(0.03346) \\
{\left[-2.19183^{* *}\right]}\end{array}$ & $\begin{array}{l}-0.301034 \\
(0.29463) \\
{[-1.02174)}\end{array}$ & $\begin{array}{l}0.086644 \\
(0.03918) \\
{[2.21160 * *]}\end{array}$ & $\begin{array}{l}0.073830 \\
(0.04052) \\
{\left[1.82206^{*}\right]}\end{array}$ \\
\hline \multicolumn{5}{|c|}{ Standard errors in () \& $t$-statistics in [ ], t-value $\left(t_{0.05}=2.042, \& t_{0.1}=1.697\right.$} \\
\hline \multicolumn{5}{|c|}{$* * \& *$ indicate statistically significant at the 0.05 and 0.1 level } \\
\hline
\end{tabular}

Source: Researcher's Compilation from E-view 
INTERNATIONAL JOURNAL OF ACADEMIC RESEARCH IN ACCOUNTING, FINANCE AND MANAGEMENT SCIENCES

Vol. 11, No. 1, 2021, E-ISSN: 2225-8329 @ 2021 HRMARS

The findings from Table 5 shows that the lagged error correction ECM (-1) included in the model to identify the long run dynamics between the co-integrating series was correctly signed (negative) and statistically significant. The ECM(-1) absolute co-efficient was 0.031810 and significant at $5 \%$ level, judging from $t$-value $\left(t_{0.05}=2.042\right)$ that was less than the absolute t-statistic $(2.51861)$ at $5 \%$ level. This confirmed that long run causality ruined among the variables, with the implication that disequilibrium that occurs in the model due to economic situation is yearly corrected at an adjustment speed of $3.18 \%$.

The results for real-GDP of one lagged period was significant with a direct effect. The $t$-statistic $(2.14475)$ was greater than the $t$-value $\left(t_{0.05}=2.042\right)$ at $5 \%$ significance level. In economic term, this implies that increase in yearly performance of finished goods and services produced which have been adjusted for price changes (i.e. inflation and deflation) is often influence by its previous year contribution. The direct and significant nature of real-GDP could be attributed to two reasons. First, real gross domestic product is an inflation adjusted sum of sectoral contribution usually within a year; therefore, its yearly performance is often more than previous estimation when expressed in baseyear prices. Secondly, real-GDP offers a better base for judging long-term national economic performance than other indicator like nominal GDP, GDP price deflator, etc. because it more easy to ascertain increase in production and service when using real-GDP due to price changes ( i.e. inflation and deflation). Therefore, previous economic growth directly influenced current growth. Also, studies like, Adeleye (2018) and Hamma (2016) arrived at the same conclusion.

The estimated coefficient of the natural log of migrants' remittances in table 4 was -0.073346 and statistically significant, implying that migrants' remittances were a robust instrument that adversely affected real-GDP in Nigeria. Specifically, the result showed an indirect relationship between migrants' remittances and real-GDP in the Nigeria's context. The economic implication of this, is that continuously increase in migrants' remittances in either cash or kind from depressed economic growth. The negative sign of the migrant remittances was contrary to the a priori expectation. The causes of this have been attributed to many factors. For instance, World Bank (1997) remarks that growth in an economy encompasses the broad quality of the country's non-financial institutions. This therefore, implies that migrant's remittance inflow also required the support of non-financial institutions to influence growth in Nigeria. The issue of brain drain is also identified as a problem facing developing countries Nigeria inclusive. Also, most of the received cash or kind by recipients are often used on temporal consumption which are not productivity like investment. In view of this, Falade (2019) recommends that migrant 's remittances could only have a lasting effect on poverty reduction and other macro-economic variables when house-hold invests money received on more productivity businesses. Also, studies that include Ahamada and Coulibaly (2013), Altin (2013), Zuniga (2011), Acosta et al., (2007) and Chami et al., (2003) that discovered in their separate studies that remittances have had adverse effects on growth; therefore, retarded growth in developing countries. On the other hand, studies that include Adeleye (2018); Iheke (2012); Koay and Choong (2013) and Muhammad et al., (2012) had confirmed that remittances had direct impact on economic growth.

The VECM result showed an inverse relationship between financial development and real-GDP but non-significant at the conventional level of $5 \%$ and $10 \%$. This finding implies that over the years financial development has not stimulated growth in Nigeria. The inverse and non-significance relationship established between financial development and economic growth may be a result of low levels of financial development in developing countries Nigeria inclusive. Also, Babatunde et al., 
(2011) revealed that the Nigerian financial sector that is part of financial development is characterized by a shortage of funds, therefore, reduce their credit to the private sector. This finding was in line with the study of Demetriades and Law (2006) and Ekpeno (2015) that discovered that financial development has zero effect on economic growth in less developed countries and SubSahara African countries. Also, many reasons for the inverse and non-significance relationships have been established in the literature. For instance, Demetriades and James (2011) attributed this to natural resource endowments. Therefore, the majority of SSA economies are driven by natural resource endowments such as crude oil, which serve as a source of income to many of the developing countries. Also, there is a low-level banking culture in developing countries, therefore, the majority of funds are in circulation. This, therefore, reduces the ability of financial institutions especially the banking sector to create funds and supply funds to the deficit side of the economy.

The result in table 5 showed that the natural log of the interaction effect of migrants' remittance and financial development index had a positive influence on real-GDP. It showed that for every $1 \%$ increase in natural log of the interaction effect of migrants' remittance and financial development index rate differential had an approximately $8.7 \%$ increase in the real-GDP in Nigeria, provided other factors were kept constant. The variable was statistically significant in influencing real-GDP, judging from the $t$-value of 2.21160 , which was greater than $t_{0.05}=2.042$ at $5 \%$ significance level. The implication of this finding is that access to credit facility by organizations, businesses, individual, and strong financial base with migrants' remittance inflow jointly influence economic growth in Nigeria. Also, study by carried out by Hamma (2016) confirmed that the interaction of remittance and financial development index boosts the economic growth of less developed countries.

The result indicated that a positive relationship existed between trade openness and real gross domestic product at $10 \%$ significance level. Implying that trade openness had a direct effect on real gross domestic product. However, the establishment of a positive influence of trade openness on growth conformed to economic theory. The argument here was that more inflow of remittance, financial aids, foreign earning and free trade boost economic growth. Additionally, trade openness may influence economic growth positively once there is evidence of foreign currency in terms of remittances inflow. This finding was inconsistent with the study of Hamma (2016) that discovered that trade openness had a direct and significant effect on economic growth.

\section{Impulse Response Result}

Impulse response result is shows below to explain shock from one variable to others. The method of impulse response adopted in this study was multiple bar chart and the decomposition employed is Cholesky-dof adjusted method for a period of 5 years. 
INTERNATIONAL JOURNAL OF ACADEMIC RESEARCH IN ACCOUNTING, FINANCE AND MANAGEMENT SCIENCES

Vol. 11, No. 1, 2021, E-ISSN: 2225-8329 @ 2021 HRMARS

Response of INRGDP to Cholesky

One S.D. Innovations

Response of LNREM to Cholesky

One S.D. Innovations
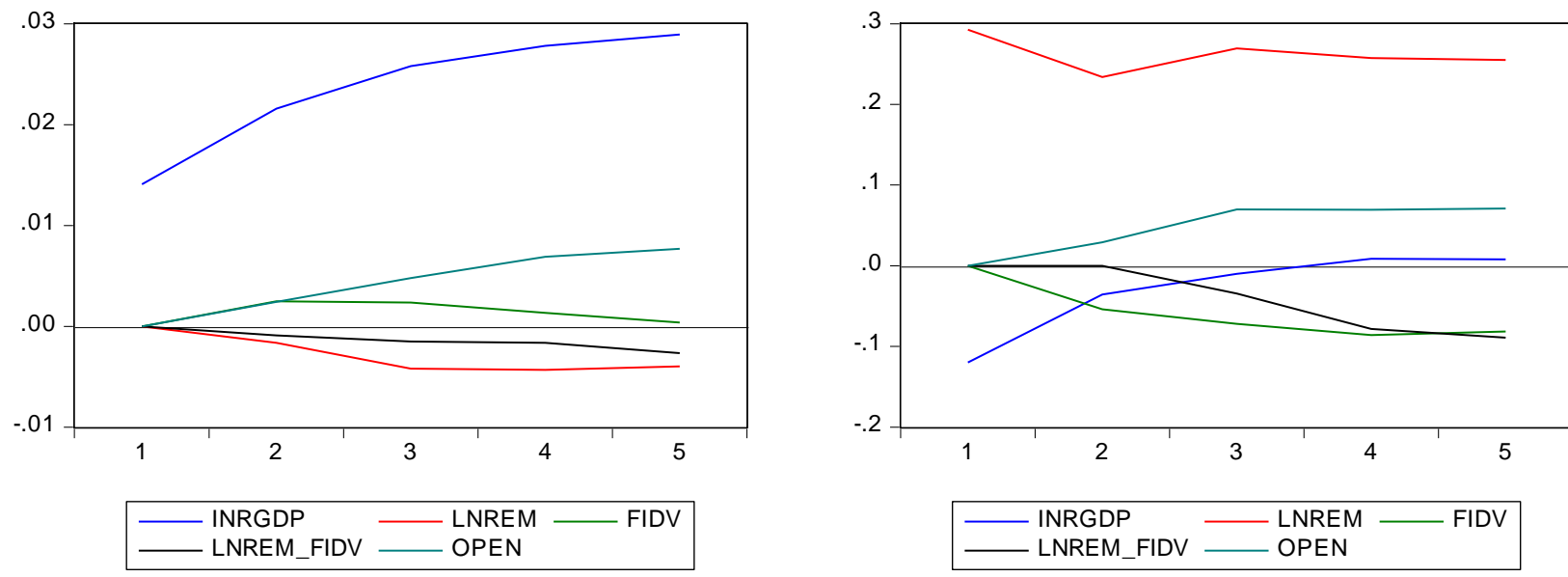

Response of FIDV to Cholesky One S.D. Innovations

Response of LNREM_FIDV to Cholesky One S.D. Innovations
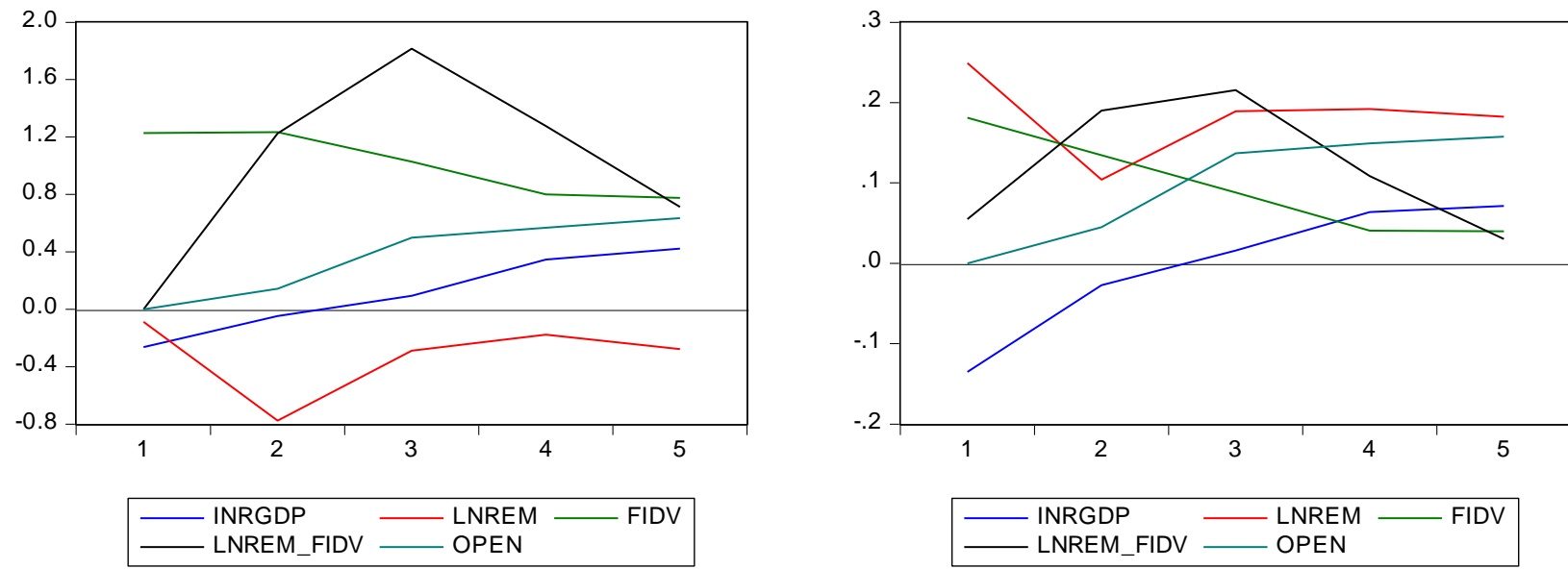

Response of OPEN to Cholesky One S.D. Innovations

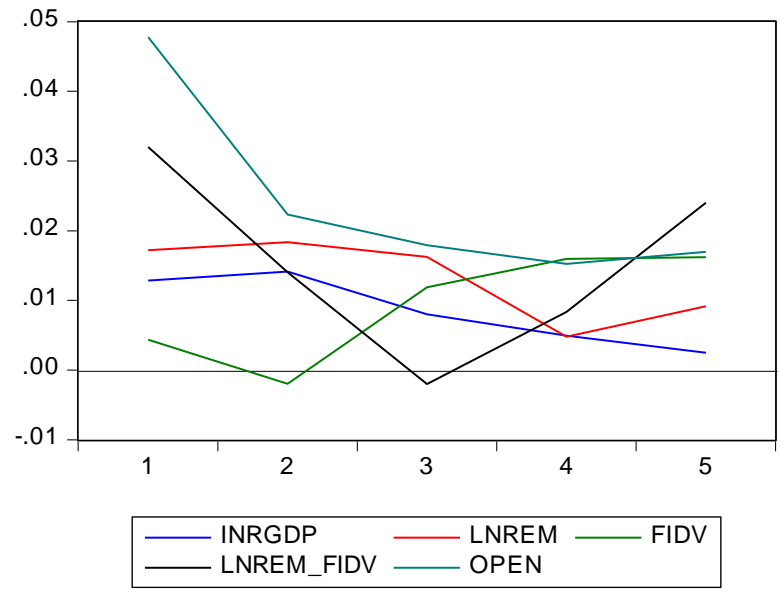


INTERNATIONAL JOURNAL OF ACADEMIC RESEARCH IN ACCOUNTING, FINANCE AND MANAGEMENT SCIENCES

Vol. 11, No. 1, 2021, E-ISSN: 2225-8329 ๔ 2021 HRMARS

For the impulse response result of real-GDP, the economic implication of this finding is that in the next five years, total additional change to real-GDP would depend on development of financial institution couple with investment of migrants' remittances received; while, its reduction in the next five years would be attributed to continuous unproductive usage of migrants' remittances received and trade openness. The response of migrants' remittances in next five year depends on both positive and negative reaction of other identified variables. The economic implication of this finding is that both productive usage of migrants' remittances received and development of financial institution have the tendency to improve and reduce migrants' remittances within the period of the next five years. Impulse response result table shows the response of financial development index in the next five (5) years. The implication of this finding is that development of financial institution couple with investment of migrants' remittances received and trade openness will jointly improve performance of financial development institution; while declining in real-GDP and migrants' remittance inflow in the next two and five years reduces financial development index respectively. In the next five years, impulse response of natural log of The interaction of migrants' remittances and financial development to other variables will be positive and negative. Implying that in the next five years, there would be increase in financial development index couple with investment of migrants' remittances received due to trade openness that allows more inflow of cash and kinds, and increase in real-GDP in the second and the half year (provided that all other variables affecting it is held constant). For trade openness, implying that increase that occurs in continuous removing trade barriers and allowing free trade is due to all the identified variables

\section{Conclusion and Recommendations}

The results from this study established that the interaction effect of remittance and financial development index and trade openness positively impact real gross domestic product; while the migrants' remittances had a negative and significant effect on it. Also, findings showed that the financial development index had no significant effect on real-GDP. This study, therefore, concludes that the degree at which remittances influence economic growth in Nigeria depends on how developed is her financial market; while migrants' remittances depresses it. The study therefore, recommends that the Central bank of Nigeria (CBN) should reduce charges on migrants' remittance inflow to Nigeria in line with other African countries to discourage remittances sent through informal channels. When the charges are reduced more migrants would deem it necessary to send the money through the formal channel, by so doing, more interest and changes that would have accrued to the government of Nigeria through the commercial bank would not be lost through the process; also, make more fund available for the financial sector. Also, the Nigeria's apex bank should improve her regulatory framework to achieve the desired economic growth. Such a regulatory framework that involves financial instruments, the payment system, financial services and financial institutions in Nigeria need to be overhauled in line with the $21^{\text {st }}$ century.

\section{References}

Acosta, P. A., Lartey, E. K. K., \& Mandelman, F. S. (2007). Remittances and the dutch disease. Federal Reserve Bank of Atlanta Working Paper No.8

Adeleye, O. K. (2017). Capital flight, international remittance and Nigerian economic growth. Journal of Public Sector Issues in Nigeria, 3(3),147-163. 
INTERNATIONAL JOURNAL OF ACADEMIC RESEARCH IN ACCOUNTING, FINANCE AND

MANAGEMENT SCIENCES

Vol. 11, No. 1, 2021, E-ISSN: 2225-8329 @ 2021 HRMARS

Adenutsi, D. E. (2011). Do remittances alleviate poverty and income inequality in poor countries? Empirical evidence from Sub-Saharan Africa. Munch Persional Repec Archive, Paper No. 37130.

Ahamada, I., \& Coulibaly, D. (2013). Remittances and growth in Sub-Saharan African countries: Evidence from panel causality test. OSE-Ouvrir la Science Economique, 2(3), 34-54.

Aladejana, S. A., Oluwalana, F. A., Alabi, J. A., \& Bolaji, S. A. (2020). An econometric analysis of external remittances on poverty reduction in Nigeria, 1986-2018. International Journal of Management Studies and Social Science Research, 2(3), 230-237.

Ali, A., \& Hassan, M. (2008). Migrant remittances and domestic investment? New evidence from panel co-integration. Discussion Paper Series EDP-1308.

Altin, G. (2013). The role of remittances on economic growth: An empirical investigation of 12 CEE Countries. International Business \& Economics Research Journal, 12(2), 20-36

Anyanwu, J. C., \& Erhijakpor, A. E. O. (2009). International remittances and economic growth in Africa. Global Development Studies, 15(3-4), 23-34.

Babatunde, O., Olayinka, M., \& Okwy, P. (2011) Impact of workers' remittances on financial development in Nigeria. International Business Research, 4(4), 13-26.

Catrinescu, M., Miguel, L., Piracha, M. \& Quillin, M. (2009). Remittances, institutions, and economic growth. World Development, 37(1), 81-92.

Chami, R., Fullenkamp, C., \& Samir, J. (2003). Are immigrant remittance flows a source of capital for development? IMF Working Paper WP/03/189.

Chee-Keong, C., \& Sok-Gee, C. (2007). Financial development and economic growth. African Journal of Business management, 2(3), 23-45.

Darrat, A. F. (1999). Are financial deepening and economic growth causally related? Another look at the evidence. International Economics Journal, 13(2), 19-35.

Demetriades, P., \& Law, S. H. (2006). Finance, institutions and economic development. International Journal of Finance and Economics, 11(3), 245-260.

Ekpeno E. (2015). Financial development, institutions and economic growth: Evidence from SubSaharan Africa. Munich Personal RePEc Archive. http://mpra.ub.uni-muenchen.de/66085/

Falade, A. O. O. (2019). Poverty reduction in Nigeria: Do remittances inflow really matter? Nigerian Studies in Economics and Management Sciences, 2(1), 26 - 33.

Giuliano, P., \& Ruiz-Arranz, M. (2005). Remittances, financial development, and growth. IMF Working Paper No. 05/234.

Hamma, I. E. (2016). Linking remittances with financial development and institutions: A study from selected MENA countries. Retrieved from http://www.ffhalshs-01655353f

Iheke, O. R. (2012). The effect of remittances on the Nigerian economy. International Journal of Development and Sustainability, 1(2), 614-621

International Monetary Fund. (2009). Do workers' remittances promote economic growth? International Monetary Fund Working Paper, WP/09/153, Washington, DC.

Jongwanich, J. (2008). Workers' remittances, economic growth and poverty in developing Asia and the Pacific countries (UNESCAP Working Paper No. 01). Retrieved from http://www.unescap.org/pdd/publications/workingpaper/wp_07_01.pdf

Jung, W. S. (1986). Financial development and economic growth: International evidence. Econ. Dev. Cultural Change, 3 (4), 336-346. 
INTERNATIONAL JOURNAL OF ACADEMIC RESEARCH IN ACCOUNTING, FINANCE AND

\section{MANAGEMENT SCIENCES}

Vol. 11, No. 1, 2021, E-ISSN: 2225-8329 @ 2021 HRMARS

Koay, Y. Y., \& Keong, C. C. (2013). The nexus between worker remittances and economic growth in Malaysia, Prosiding Persidangan Kebangsaan Ekonomi Malaysia Ke, 8(1), 507-515.

Liu, X., Song, H., \& Romilly, P. (1997). An empirical investigation of the causal relationship between openness and economic growth in China. Appl. Econ., 29, 1679-1686.

Muhammad, J., Arif, U., \& Qayyum, A. (2012). Impact of remittances on economic growth and poverty in Pakistan. Journal of Academic Research International, 2(1), 12- 20 2, N

Ojapinwa, T. V. (2015). Workers remittances and economic performance in Nigeria: An econometrics analysis. Journal of Economics, 4(14), 295-301.

Pradhan, G., Upadhyay, M., \& Upadhyaya, K. (2008). Remittances and economic growth in developing countries. The European Journal of Development Research, 20(3), 12-33.

Ratha, D. (2005). Leveraging remittances for development. Migration policy institute, World Bank, Washington, DC.

World Bank. (1997). World Bank development report 1997: The State in a changing world. New York: Oxford University Press.

World Bank. (2010). World development report: Making services working for the poor. The World Bank, Washington, DC.

World Bank. (2013). Migration and remittances fact book 2011. Washington, D.C.

World Bank. (2017). Migration and remittances: Recent development and Outlook. The World Bank, Washington, DC.

Zuniga, M. C. (2011). On the path to economic growth, do remittances help? Evidence from panel VAR. The Developing Economies, 49(2), 171-202. 